\title{
Tko je moj bližnji? (Lk 10,29)
}

\section{Isusov odnos prema drugomu i drugačijemu}

Silvana Fužinato*

\begin{abstract}
Sažetak
Pitanje odnosa prema drugomu i drugačijemu pitanje je s kojim se susreće svaki čovjek. Promišljajući o Isusovu dijalogu sa zakonoznancem o zapovijedi ljubavi (Lk 10,25-37), članak pokušava odgovoriti na pitanje: Tko je moj bližnji? Pokušava se definirati Isusov odnos prema drugima i drugačijima. Odlomak 10,25-37 iz Lukina evanđelja analiziramo komunikacijskim pristupom, koji pripada semiotičkoj metodi interpretacije Svetoga pisma i koji posebnu pozornost pridaje pragmatičkoj snazi i ulozi teksta.
\end{abstract}

Ključne riječi: Samarijanac; Zakon; ljubav; bližnji; odgovornost; solidarnost

\section{Uvod}

Pitanje drugoga i drugačijega jedno je od svevremenskih pitanja s kojima se ponekad susrećemo na vrlo dramatičan način. Primjerice, velika migracijska kretanja i otvoreno ili potisnuto nasilje koje prožima međuljudske odnose mijenjaju čovjekovu percepciju o sebi samom, drugom i svijetu (Grilli, 2013, 7). U susretu s drugim i drugačijim, koji često dovodi u pitanje osobnu sigurnost, stavove i uvjerenja, u čovjeku se nerijetko rađa želja za podređivanjem, dominiranjem ili inkorporiranjem drugoga, umjesto da ga prepozna i prihvati kao različitoga. U susretu s drugima pitamo se kakav stav zauzeti. Postoji li granica u prihvaćanju drugoga i mjera u iskazivanju solidarnosti? U korijenu tih i sličnih pitanja nalazi se ključno pitanje: Tko je moj bližnji?

Odgovore na ta pitanja pokušavamo pronaći u egzegetsko-teološkoj analizi Isusove prispodobe o milosrdnom Samarijancu (Lk 10,25-37) u komunikacijskoj perspektivi. Iako je Biblija, jednako kao i cjelokupna tradicija Crkve, konstantno inzistirala na Riječi koja se ne vraća Bogu bez ploda a da nije učinila ono što je Bog htio i da nije ispunila ono zbog čega ju je poslao (usp. Iz 55,11), interpreta-

* Doc. dr. sc. Silvana Fužinato, Katolički bogoslovni fakultet u Đakovu Sveučilišta J. J. Strossmayera u Osijeku. Adresa: P. Preradovića 17, p. p. 54, 31400 Đakovo, Hrvatska. ORCID iD: https:// orcid.org/0000-0002-6777-1526. E-adresa: fuzinatosilvana@gmail.com 
cija biblijskih tekstova u komunikacijskoj perspektivi, koja posebnu pozornost pridaje pragmatičkoj ulozi i snazi teksta, novija je datost. Riječ je o egzegetskom pristupu koji nalazimo u dokumentu Tumačenje Biblije u Crkvi (Papinska biblijska komisija, 2005, 53-56), nakon retoričke i narativne analize. Kao takav manje je poznat te među egzegetskim metodama i pristupima najmanje zastupljen, ali istodobno je i najaktualniji jer povezuje biblijski tekst s čitateljima današnjega vremena, nastojeći da pritom ne ubije ni prošlost ni sadašnjost, nego da ih dovede do plodonosnoga dijaloga. Naime, za razliku od povijesno-kritičke metode, koja naglašava napose povijesne činjenice, stvarne autore, zajednicu povijesnih čitatelja i dr., ne pridajući dovoljno pozornosti konačnomu obliku biblijskoga teksta i poruci koju je priopćavao, kao i za razliku od strukturalizma, koji posvećuje pozornost samo čitateljima današnjega vremena i načinu na koji mogu uporabiti biblijske tekstove u sadašnjem trenutku, interpretacija biblijskih tekstova u komunikacijskoj perspektivi čitatelja današnjega vremena potiče na dijalog s biblijskim tekstom, ukazujući ne samo na značenje teksta, nego i na reakcije, promjene i djelovanje koje tekst u njemu pobuđuje i zahtijeva. ${ }^{1}$

U prvom dijelu osvrćemo se na literarni kontekst u kojem Luka smješta taj izvještaj, pružajući čitatelju interpretativne koordinate. U drugom dijelu posvećujemo pozornost analizi narativnih, sintaktičkih i semantičkih elemenata na temelju kojih određujemo komunikacijsku artikulaciju odlomka Lk 10,25-37, koja uz literarni kontekst predstavlja nužni korak za ispravno tumačenje teksta, čemu pristupamo u trećem dijelu. Na kraju smo pokušali definirati Isusov stav prema drugomu i drugačijemu, koji smo pozvani utjeloviti i autentično svjedočiti u svojim svakodnevnim susretima, unutar, jednako kao i izvan naših obiteljskih, vjerskih i društvenih zajednica.

\section{Literarni kontekst Lk 10,25-37}

Parabola o milosrdnom Samarijancu (Lk 10,25-37) nalazi se u kontekstu Isusova puta prema Jeruzalemu (Lk 9,51-13,21), koji Luka započinje svečanom izjavom o Isusovoj čvrstoj odluci o odlasku u Jeruzalem (Lk 9,51). Za ispravno razumijevanje toga dijela, kojemu Luka posvećuje čak $40 \%$ ukupnoga sadržaja svojega evanđelja (Michelini, 2016, 54), potrebno je uočiti uporabu grčkoga izraza analēmpsis ("uzašašće, uznesenje”) (Popović, 2016, 23). Dakako, u topografskom smislu grad se je nalazio na uzvisini. Međutim, taj izraz tu ne označava samo Isusov fizički uzlazak prema Jeruzalemu, nego u sebi sadržava i duboko teološko značenje. Isusov put prema Jeruzalemu nije toliko zemljopisni hodogram koliko nutarnji hod, konstantno usmjeravanje njegove volje, koje Luka izražava izrazom analèmpsis. Riječ je o putu koji Isus poduzima u svjetlu Božjega spasenj-

1 Za detaljniji prikaz interpretacije Svetoga pisma u komunikacijskoj perspektivi vidi: Fužinato, Silvana; Grilli, Massimo (2019). Riječ Božja u ljudskom jeziku. Tumačenje Biblije u komunikacijskoj perspektivi. Zagreb: Glas Koncila. 
skoga nauma, tj. prema njegovu ispunjenju u muci, smrti, uskrsnuću i uzašašću (Grilli, 2012, 91-92).

Isusov put prema Jeruzalemu, osim ispunjenja Očeva spasenjskoga nauma, karakterizira i nasljedovanje njegovih učenika (Zimmermann, 2011, 850). Isusov put, put je i njegovih učenika. Naime, uzlazeći prema Jeruzalemu, Isus formira svoje učenike, pozivajući ih na preuzimanje osobne odgovornosti u odnosima koji određuju njihov život: odnos s Kristom i preko Krista s Bogom te odnos prema bližnjemu (Grilli, 2012, 92). Doista, pogledamo li tekst u cjelini, uočavamo tri vrlo sažeta izvještaja o Isusovu susretu s različitim osobama u kojima Luka poziva svoje čitatelje na promišljanje i donošenje osobne odluke.

Dok su išli putom Isusu se je netko (grč. tis) ${ }^{2}$ obratio riječima: »Za tobom ću kamo god ti pošao« (Lk 9,57). »Lisice imaju jazbine, ptice nebeske gnijezda, a Sin Čovječji nema gdje bi glavu naslonio« (Lk 9,58), Isusov je odgovor u kojem poziva učenike na preuzimanje odgovornosti. Nasljedovati Isusa znači poput njega, koji nema gdje nasloniti glavu jer je zbog neprestanoga odbacivanja ljudi primoran putovati dalje, hoditi prema križu. Drugomu, koji mu je na njegov poziv »Pođi za mnom!« odgovorio molbom za pokapanjem oca (Lk 9,59), Isus otkriva drugi kriterij za vrjednovanje života i smrti, rekavši mu: »Pusti neka mrtvi pokapaju svoje mrtve, a ti idi i navješćuj kraljevstvo Božje« (Lk 9,60). Isus se ne protivi pokapanju roditelja, što je svaki učenik dužan učiniti, nego ga poziva na prihvaćanje logike kraljevstva. Svaki učenik pozvan je graditi svoje odnose na temeljnom odnosu Krista i njegova kraljevstva. Teško je razumjeti i prihvatiti taj Isusov radikalan poziv. No u izvornom tekstu nalazi se riječ koju ne smijemo zanemariti i koju trebamo ozbiljno uzeti u obzir. Riječ je o vremenskom prilogu prōton ("prije"), koji se odnosi na kraljevstvo i Isusov navještaj (Grilli, 2012, 94). I drugomu koji ga moli: »Za tobom ću, Gospodine, ali dopusti mi da se prije oprostim sa svojim ukućanima « (Lk 9,61) Isus odgovara: »Nitko tko stavi ruku na plug pa se obazire natrag, nije prikladan za kraljevstvo Božje« (Lk 9,62). Spasenjskom zahvatu koji Bog u njemu ostvaruje učenik ne može postaviti nijedan uvjet i nijednu životnu situaciju. Slijediti Isusa znači bezuvjetno prionuti uz njegovu osobu, izići iz samoga sebe i iz svojega vlastitoga poimanja života i prioriteta $u$ postizanju osobnoga uspjeha (Grilli, 2012, 95).

Prispodoba o milosrdnom Samarijancu nalazi se, dakle, u kontekstu Isusova puta u Jeruzalem, na kojem Isus poučava i poziva svoje učenike na radikalan odnos s Bogom i njegovim kraljevstvom. Nakon poziva na preuzimanje osobne odgovornosti, bilo u naviještanju kraljevstva Božjega, bilo u izgradnji osobnoga odnosa s Bogom, Isus poziva svoje učenike na izgradnju odnosa s bližnjim.

2 Luka ne precizira o kome je riječ kako bi se čitatelj mogao s njim lakše poistovjetiti. 


\section{Komunikacijska artikulacija Lk 10,25-37}

Prvi korak u razumijevanju svakoga, jednako tako i biblijskoga teksta određivanje je njegove komunikacijske artikulacije. Ako u delimitaciji Lk 10,25-37 nema sumnje jer je početak i završetak izvještaja jasno određen promjenom mjesta i protagonista, jednako ne možemo reći i za njegovu strukturu, koju autori određuju na različite načine. ${ }^{3}$ No, pažljiva analiza leksičkih, sintaktičkih i retoričkih elemenata ukazuje na trodijelnu strukturu.

U redcima 10,25-30a Luka donosi dijalog između nekoga zakonoznanca i Isusa. Uporabom izraza kai idou ("i gle”) na početku 10,25 autor privlači čitateljevu pozornost ukazujući na važnost sljedećega događaja (Nolli, 1993, 487). Sadržaj dijaloga jasno je određen pitanjem zakonoznanca: »Što mi je činiti da život vječni baštinim? « (Lk 10,25a) i Isusovim odgovorom: »To čini i živjet ćeš« (Lk 10,28).

Nagli prijelaz na pripovjedni dio u Lk 10,30b označava početak drugoga središnjega dijela, u kojem uočavamo dva bitna narativna trenutka. U prvom evanđelist uvodi čitatelje u Isusovu prispodobu o nekom čovjeku koji je na putu iz Jeruzalema u Jerihon upao među razbojnike, koji ga svukoše i izraniše ostavivši ga na cesti polumrtva (Lk 10,30b). U drugom Luka prikazuje reakcije svećenika, levita i Samarijanca (Lk 10,31-35). Potrebno je uočiti kontrast između identičnih reakcija svećenika i levita koji, vidjevši pretučena čovjeka, zaobiđoše ga (antiparēlthen) (Lk 10,31-32), i reakciju Samarijanca, koji vidjevši ga sažali se nad njim (esplanhnisthē) (Lk 10,33). Svim tim reakcijama prethodio je pogled koji u izvornom grčkom jeziku autor opisuje participom aorista aktivnoga glagola horaō ("vidjeti”), dovodeći čitatelja u stanje iščekivanja. Kontrast je naglašen i imenicom Samaritēs (“Samarijanac”), koju u izvornom tekstu na grčkom jeziku evanđelist donosi na početku rečenice, stavljajući naglasak na Samarijanca i na njegovo djelovanje, u čijem se središtu nalazi glagol splanhnizomai ("sažaliti se").

Treći dio nastavak je dijaloga između Isusa i zakonoznanca (Lk 10,36-37). Na pitanje zakonoznanca na kraju prvoga dijaloga: »A tko je moj bližnji? « (Lk 10,30), Isus sada odgovara protupitanjem: »Što ti se čini, koji je od ove trojice bio bližnji onomu koji je upao među razbojnike? «(Lk 10,36). Uspoređujući dijaloge uočavamo paralelizam između izraza: »Što mi je činiti da život vječni baštinim? « (Lk 10,25a) i »To čini i živjet ćeš« (Lk 10,28) iz prvoga s »Onaj koji mu iskaza milosrđe « $(\mathrm{Lk} 10,37)$ i »Idi pa i ti čini tako! « (Lk 10,37) iz drugoga dijaloga. Osim toga, u Isusovoj zapovijedi »Idi pa i ti čini tako!« uporaba osobne zamjenice sy (“ti”) nije nužna. Dakako, riječ o autorovoj namjernoj uporabi s ciljem naglašavanja poziva na osobno odgovorno djelovanje.

3 Usp. paralelnu strukturu koju donosi Zimmermann (2011, 850) ili strukturu u dvije faze koju predlaže Bovon $(2007,104)$. 
Pogledamo li komunikacijsku artikulaciju u cjelini, otkrit ćemo izvrsnu autorovu strategiju u tri dijela: pitanje (Lk 10,25-30a), transformacija čitatelja putem parabole (Lk 10,30b-35) i odgovor (Lk 10,36-37).

Na temelju analize retoričkih, sintaktičkih i leksičkih elemenata komunikacijsku artikulaciju Lk 10,25-37 možemo prikazati na sljedeći način: ${ }^{4}$

Tablica 1. Dijalog u Lk 10,25-30a

Table 1. The dialogue in Lk 10:25-30a

\begin{tabular}{|c|c|c|c|}
\hline 25 & I gle, neki zakonoznanac & usta i, da ga iskuša, upita: & $\begin{array}{l}\text { "Učitelju, što mi je činiti } \\
\text { da život vječni baštinim?" }\end{array}$ \\
\hline 26 & A on & mu reče: & "U zakonu što piše? Kako čitaš?" \\
\hline 27 & & Odgovori mu onaj: & $\begin{array}{l}\text { "Ljubi Gospodina Boga svojega } \\
\text { iz svega srca svoga, } \\
\text { i svom dušom svojom, } \\
\text { i svom snagom svojom, } \\
\text { i svim umom svojim; } \\
\text { i svoga bližnjega kao sebe samoga!" }\end{array}$ \\
\hline 28 & & Reče mu na to Isus: & $\begin{array}{l}\text { "Pravo si odgovorio. } \\
\text { To čini i živjet ćeš." }\end{array}$ \\
\hline 29 & Ali hoteći se opravdati & reče on Isusu: & “A tko je moj bližnji??" \\
\hline $30 \mathrm{a}$ & Isus prihvati i & reče: & \\
\hline
\end{tabular}

Tablica 2. Pripovjedni dio u 10,30b-35

Table 2. The parabolic section in Lk 10:30b-35

\begin{tabular}{|c|c|c|}
\hline $30 b$ & $\begin{array}{l}\text { “Čovjek neki } \\
\text { među razbojnike } \\
\text { koji ga svukoše i izraniše }\end{array}$ & $\begin{array}{l}\text { silazio iz Jeruzalema u Jerihon. } \\
\text { Upao } \\
\text { pa odoše ostavivši ga polumrtva. }\end{array}$ \\
\hline 31 & $\begin{array}{l}\text { Slučajno je } \\
\text { neki svećenik } \\
\text { vidje ga i }\end{array}$ & $\begin{array}{l}\text { onim putem silazio } \\
\text { zaobiđe. }\end{array}$ \\
\hline 32 & $\begin{array}{l}\text { A tako i levit: } \\
\text { prolazeći onuda, } \\
\text { vidje ga i }\end{array}$ & zaobiđe. \\
\hline 33 & $\begin{array}{l}\text { Neki Samarijanac putujući } \\
\text { i vidje ga }\end{array}$ & $\begin{array}{l}\text { dođe do njega } \\
\text { sažali se, }\end{array}$ \\
\hline
\end{tabular}

4 Kompozicijska shema Lk 10,25-37 prikazuje tekst podijeljen prema kriteriju različitih komunikacijskih razina. Prvi stupac prikazuje drugi komunikacijski stupanj u kojem autor oblikuje narativnu podlogu glagolima u imperfektu i participu. Drugi stupac prikazuje prvi stupanj komunikacije u kojem dolaze do izražaja glagoli u aoristu i historijskom prezentu koji su nositelji radnje. Treći stupac odnosi se na upravni govor. O tom načinu strukturiranja biblijskoga teksta, koji se temelji na teoriji H. Weinricha, usp. Niccacci, 1992. 


\begin{tabular}{|l|l|l|l|}
\hline 34 & $\begin{array}{l}\text { pa mu pristupi i } \\
\text { zalivši ih uljem i vinom. } \\
\text { Zatim ga postavi na svoje živinče, } \\
\text { i }\end{array}$ & $\begin{array}{l}\text { povije rane } \\
\text { odvede ga u gostinjac } \\
\text { pobrinu se za nj. }\end{array}$ & $\begin{array}{l}\text { dva denara, } \\
\text { dade ih gostioničaru } \\
\text { i reče: }\end{array}$ \\
\hline 35 & Sutradan izvadi & $\begin{array}{l}\text { Pobrini se za njega. } \\
\text { Ako što više potrošiš, } \\
\text { isplatit ću ti kad se budem vraćao." }\end{array}$ \\
\hline
\end{tabular}

Tablica 3. Dijalog u Lk 10,36-37

Table 3. The dialogue in Lk 10:36-37

\begin{tabular}{|l|l|l|l|}
\hline 36 & & & $\begin{array}{l}\text { "Što ti se čini, koji je od ove trojice } \\
\text { bio bližnji onomu koji je upao } \\
\text { među razbojnike?" }\end{array}$ \\
\hline 37 & $\begin{array}{l}\text { On } \\
\text { Nato }\end{array}$ & $\begin{array}{l}\text { odgovori: } \\
\text { mu reče Isus: }\end{array}$ & $\begin{array}{l}\text { "Onaj koji mu iskaza milosrđe." } \\
\text { "Idi i } \text { ti čini tako!" }\end{array}$ \\
\hline
\end{tabular}

\section{Isusovo učenje o odnosu prema drugomu i drugačijemu}

Pitanje odnosa prema bližnjemu središnje je pitanje Isusova dijaloga s nekim zakonoznancem koji Luka donosi unutar rasprave o prvoj ili najvećoj zapovijedi koju susrećemo i kod ostalih evanđelista. No za razliku od Luke, koji ju donosi na početku Isusova puta prema Jeruzalemu, kod Mateja (22,34-40) i Marka (12,2831) nalazi se unutar Isusove rasprave s pismoznancima za vrijeme posljednjih dana njegova djelovanja u Jeruzalemu. U tom svjetlu razvidno je da je riječ o kardinalnom stupu, o srcu Zakona koje je u praktičnom izvršavanju dovodilo do konkretnoga pitanja o identitetu bližnjega i o odnosu prema njemu.

\subsection{Tko je moj bližnji?}

»Učitelju, što mi je činiti da život vječni baštinim?«(Lk 10,25) pitanje je koje zakonoznanac, dobar poznavatelj Tore, ${ }^{5}$ postavlja Isusu želeći ga iskušati. U stilu rabina (Crimella, 2015, 200) Isus na pitanje odgovara protupitanjem: »U zakonu što piše? Kako čitaš? « (Lk 10,26), potičući ga na osobno traženje odgovora u Zakonu i na njegovo tumačenje. ${ }^{6}$ Naime, tim pitanjem Isus ukazuje na razliku između pisanoga zakona i različitih mogućih interpretacija koje ovise o čitateljevoj odgovornosti (Simian-Yofre, 2011, 55). Za razliku od zakonoznanca (Lk 10,25), Isus ga ne želi iskušati, nego proširuje područje dijaloga vodeći ga na zajednički teren - Zakon. Zakon je određen, ali svaki čitatelj odgovoran je za njegovo

5 Tipično Lukin izraz nomikos (Lk 10,25; 11,45.46.52; 14,3) upućuje na kategoriju osoba koje su bile specijalizirane u poznavanju židovskoga Zakona (Crimella, 2015, 200).

6 Grčki $t i$ ("što") odnosi se na Zakon, a pōs ("kako") na njegovo tumačenje. 
osobno tumačenje (Michelini, 2016, 62). U svojem odgovoru zakonoznanac, s jedne strane, podsjeća na zapovijed ljubavi prema Bogu citirajući riječi iz Shemà Israel: »Ljubi Gospodina Boga svojega iz svega srca svoga, i svom dušom svojom, i svom snagom svojom, i svim umom svojim « (Pnz 6,5), a s druge, naglašava ljubav prema bližnjemu citirajući Lev 19,18 »i svoga bližnjega kao sebe samoga«.7 Riječ je o jedinstvenom činu ljubavi prema Bogu i bližnjemu koji prožima sve dimenzije čovjekova bića. ${ }^{8}$ Naime, u židovstvu, jednako kao i u kršćanstvu, ljubav nije samo osjećaj, nego i odluka koju čovjek donosi pred Bogom u vjernosti njemu i u služenju bratu čovjeku (Grilli, 2012, 96).

Pitanje »A tko je moj bližnji?«, kojim se zakonoznanac želi opravdati pred Isusom, ${ }^{9}$ ukazuje na raspravu unutar židovstva onoga vremena vezanu uz problematiku definiranja pojma bližnjega, koji se je shvaćao na različite načine. Tako se prema rabinskom razumijevanju u Lev 19,18 pojam bližnjega odnosio na sunarodnjaka, tj. na brata Židova dok su drugi u njemu vidjeli brata po Zakonu, tj. onoga koji je opsluživao Toru. Osim toga u Lev 19,33-34 pojam bližnjega uključuje sve ljude koji kao stranci borave u Izraelu. Grilli $(2012,97)$ ukazuje i na mišljenje koje se temelji na različitoj vokalizaciji hebrejskoga glagola $\mathrm{ra}$. Naime, ako se vokalizira s patahom (_) tada pridjev ra ' znači "zao”, "bezbožan”, "grješan”, a ako se vokalizira s cere (..) u tom slučaju imenica re 'a znači "brat”, "bližnji” (Amerl, 1997, 274). Pojedini rabini, pozivajući se na različitu vokalizaciju koja dovodi do suprotnih značenja, zaključuju da je bližnji mogao biti i zao, bezbožan i grješan čovjek.

Poteškoća definiranja izraza bližnji vezana je i uz višestruku mogućnost čitanja Lev 19,18: »Ne osvećuj se! Ne gaji srdžbe prema sinovima svoga naroda. Ljubi bližnjega svoga kao samoga sebe. Ja sam Jahve! «U središtu tog retka izrazi su ljubiti i bližnji u uskom odnosu s kāmôkā, koji možemo prevesti na dva načina: 1. ljubiti bližnjega svojega kao sebe samoga; 2. ljubiti bližnjega svojega koji je kao što si ti sam. Targum Neofiti preferira drugi način čitanja, za razliku od Septuaginte i Vulgate koje se opredjeljuju za prvo (Cifrak, 2012, 576-577).

Na kraju ovoga kratkoga prikaza poimanja bližnjega u židovstvu možemo zaključiti da zakonoznanac, kao učitelj Zakona osobno zainteresiran za polemično pitanje, želi saznati kakav je Isusov stav i koji su njegovi kriteriji za određivanje bližnjega, kojega Zakon nalaže ljubiti kao sebe samoga. ${ }^{10}$

7 S obzirom na navedeni odgovor potrebno je ukazati na činjenicu da sve do danas ne postoji siguran židovski dokument koji na tako tijesan način ujedinjuje te dvije zapovijedi (Crimella, 2015, 200).

8 Srce evocira volju i afektivnost, duša spoznaju i duhovni senzibilitet, snaga osobnu energiju i razum inteligenciju (usp. Morris, 1983, 191).

9 Prema Fitzmyeru $(1985,886)$ zakonoznanac je želio pokazati da je pitanje koje je netom postavio Isusu o tome kako baštiniti život vječni (usp. Lk 10,25) opravdano, tj. da je imao razlog postaviti ga unatoč tako jednostavnom odgovoru. Tako smatra i Michelini $(2016,67)$.

10 Fausti (1994, 390) smatra da pitanje nije "koga trebam ljubiti" (quis diligendus), nego "tko me ljubi” (quis diligens) jer nitko ne može ljubiti ni sebe, ni drugoga, ni Boga ako prije nije iskusio blizinu onoga tko ga ljubi. 


\subsection{Stav svećenika, levita i Samarijanca prema bližnjemu}

Na postavljeno mu pitanje Isus odgovara parabolom o milosrdnom Samarijancu (Lk 10,30b-37), ukazujući na vrlo ozbiljan problem, jer ako je s jedne strane Zakon koji je trebalo izvršavati, s druge je strane polumrtav čovjek. U Isusovu kratkom i dramatičnom prikazu nekoga čovjeka koji je silazio iz Jeruzalema u Jerihon i kojega razbojnici svučena i izranjena ostavljaju na cesti polumrtva na literarnoj razini potrebno je uočiti dvije značajke. Prva se odnosi na neodređeni pridjev tis ("neki") uz imenicu anthropos ("čovjek"), kojim autor ne otkriva identitet žrtve, naglašujući univerzalnost. Druga značajka vezana je uz njegov silazak iz Jeruzalema u Jerihon, koji autor opisuje glagolom u imperfektu katebainen. Riječ je o dugačkom (oko $27 \mathrm{~km}$ ) i opasnom putovanju vrlo usamljenim pustinjskim putem i klancem, koji je privlačio razbojnike i lopove koji su iznenada napadali i pljačkali prolaznike (Bovon, 2007, 111).

U nastavku Isus prikazuje reakcije svećenika, levita i Samarijanca. ${ }^{11}$ Pogledajmo o kakvim je reakcijama riječ. Svećenik i levit prolazeći onim putem vidješe ga i zaobiđoše, točnije prijeđoše na drugu stranu. ${ }^{12}$ Iako Luka ne navodi razlog njihova prelaska na drugu stranu i izbjegavanja pomoći unesrećenomu, većina egzegeta (Cifrak, 2012, 580; Spinetoli, 1982, 263; Morris, 1983, 192; Bauckham, 1998, 477-478) smatra da je riječ o strahu od obrednoga onečišćenja. Naime, službenici kulta (svećenici i leviti) postajali su neprikladni za vršenje liturgijskih obreda ako su se onečistili, primjerice dodirom mrtvoga tijela, bilo čovjeka ili životinje, ili tjelesnim izljevom (usp. Br 10,11-13; Lev 21,1-4.11). No, prema Giuliu Micheliniu taj razlog nije uvjerljiv s obzirom na činjenicu da je Lev 21 vrijedio samo za svećenika, ali ne i za levita. Osim toga, ranjeni o kojem se govori u paraboli nije mrtav (Michelini, 2016, 74). U prilog tim opservacijama treba napomenuti i činjenicu da su neke rabinske škole ukazivale na primat spašavanja ljudskoga života te u skladu s tim nisu priječile interveniranje u slučaju smrtne opasnosti (Grilli, 2012, 98). Zašto su svećenik i levit prešli na drugu stranu, pitanje je koje unatoč različitim odgovorima i dalje ostaje otvoreno. No, ne krije li se upravo u njemu genijalnost Lukina izvještaja? Odgovor na to pitanje čitatelj je pozvan pronaći ne u paraboli, nego u osobnom životu (Schottroff, 2007, 213).

Treći koji je prolazio tim putem neki je Samarijanac. Riječ je o heretiku i strancu, o pripadniku (u očima Židova) nečistomu, poganskomu i neprijateljskomu narodu. Samarijanci su bili jedna od sastavnica židovskoga palestinskoga konteksta, no geografski, etnički i religiozno bili su odvojeni od službenoga židovstva. Početak i razlog odvajanja seže u vrijeme pada Sjevernoga Kraljevstva 721. pr. Kr., nakon kojega je došlo do miješanja izraelskoga pučanstva s poganskim doseljenicima iz različitih provincija Asirskoga Carstva, koji su sa sobom donijeli svoja lokalna vjerovanja i običaje. Do sukoba sa stanovništvom Južnoga

11 Neodređeni pridjev tis ("neki") uz imenice svećenik i Samarijanac naglašava univerzalnost (Cifrak, 2012, 578).

12 Glagol koji Luka rabi za opis njihova djelovanja je antiparèlthen, koji je sastavljen od prijedloga anti i para te od glagola erhomai, što bi značilo "prijeći na drugu stranu” (Ernst, 2004, 293). 
Kraljevstva došlo je nakon njihova povratka iz babilonskoga sužanjstva, kada su povratnici odbili pomoć žitelja Samarije u izgradnji jeruzalemskog hrama, jer su ih s kultnoga motrišta smatrali nečistima. Konačno razdvajanje dogodilo se je 325. pr. Kr., kada su Samarijanci na brdu Gerizimu sagradili vlastiti hram. O njihovu neprijateljskom odnosu svjedoči i Josip Flavije u spisu Židovske starine 20,118-135, govoreći o zlostavljanju židovskih hodočasnika na putu prema Jeruzalemu od strane Samarijanaca. S druge strane, Židovi su ih smatrali opsjednutima i nečistima, izbjegavali su njihova naselja, a zajedničko blagovanje smatrano je teškim grijehom. Neprijateljsko ozračje očitovalo se je i u samom nazivu. Naime, kad bi Židov nekoga htio povrijediti, nazvao bi ga Samarijancem (usp. Iv 8,48).

Za razliku od hramskih službenika, koji su u Izraelu bili najviše dužni izvršavati zapovijed ljubavi, a koji se ne susreću s izranjenim sunarodnjakom, nego se, uvjetovani obrednim odredbama i egoističnim impulsima, udaljuju od njega, neki Samarijanac, koji je poput njih prolazio tim putem i koji ga je jednako kao i oni vidio, ne prelazi na drugu stranu, nego mu prilazi prožet osjećajima dubokoga milosrđa i smilovanja. Izranjeno i nemoćno tijelo jednoga budi pažljivo i osjetljivo srce drugoga (Bovon, 2007, 112).

Osjećaje koje Samarijanac osjeća u susretu s izranjenim čovjekom Luka opisuje glagolom splanhnizomai ("sažaliti se", "biti ganut", "smilovati se”), koji ukazuje na osjećaje vlastite majčinoj utrobi: milosrđe i samilost. ${ }^{13}$ Zanimljivo je uočiti niz detalja kojima autor opisuje reakciju toga heretika i stranca, naglašujući njegovo odgovorno i zauzeto djelovanje: dođe, vidje, sažali se, pristupi, povije mu rane zalivši ih uljem i vinom, ${ }^{14}$ posadi ga na svoje živinče, odvede ga u gostinjac ${ }^{15}$ i pobrinu se za nj, ostavi gostioničaru dva denara ${ }^{16}$ da se pobrine za njega s obećanjem naknade pri povratku u slučaju većih izdataka od predviđenih (Lk 10,33-34). Tako Luka stvara snažan kontrast između svećenika i levita, koji čine samo jednu gestu (zaobilaze ga) i Samarijanca, koji na sve načine i služeći se svim raspoloživim sredstvima čini sve što je u njegovoj moći kako bi spasio život polumrtva neznanca (Grilli, 2012, 98). Štoviše, za razliku od svećenika i levita, koji se, zarobljeni obrednim propisima, nisu željeli zaustaviti ni na trenutak, Samarijanac se zaustavlja i pruža pomoć unesrećenomu te obećava da će se na povratku vratiti i izmiriti moguce dodatne troškove liječenja.

13 Tim glagolom Luka opisuje i Isusove osjećaje u susretu s udovicom iz Naina (Lk 7,13), kao i osjećaje milosrdnog Oca (Lk 15,20; usp. Walter, 2004, 1389). Stoga ne začuđuje što crkveni otci pitajući se tko je milosrdni Samarijanac zaključuju da je sam Isus (Just, 2006, 262-264).

14 U ondašnje vrijeme ulje pomiješano s vinom upotrebljavalo se za dezinfekciju otvorenih rana i za ublažavanje bolova.

15 Izraz pandoheion, koji se u Novom zavjetu nalazi samo tu, upućuje na odmorište, više za životinje nego za ljude, koji su se nalazili u hitnoj potrebi, danju za odmor i noću kako bi izbjegli opasnosti na putu (Maly, 2016, 15).

16 Dva denara, koja su bila zarada dviju dnevnica, bila su dovoljna za barem dva tjedna boravka u odmorištu (Crimella, 2015, 201). 


\subsection{Komu sam ja bližnji?}

Pitanjem »Što ti se čini, koji je od ove trojice bio bližnji onomu koji je upao među razbojnike? « (Lk 10,36) Isus premješta središte problema, razbijajući ondašnje kazuističko poimanje bližnjega. Nije nužno znati tko je moj bližnji prema zakonu, krvnom srodstvu i običajima koji se primjenjuju u međuljudskim odnosima i različitim kulturnim ili društvenim kontekstima. Temeljno i odlučujuće pitanje je: Komu sam ja bližnji? (Grilli, 2012, 98). Drugim riječima, Isusovo zaključno pitanje ne odnosi se na onoga komu je pomoć potrebna, nego na onoga koji je pružio pomoć (Müller, 1996, 108). Pozornomu čitatelju ne može promaknuti promjena uporabe izraza bližnji. Na početku je dijaloga zakonoznanac želio znati tko je bližnji kojega je pozvan ljubiti kao sebe samoga. Za razliku od 29. retka, u kojem je izraz bližnji uporabljen kao objekt, u 36. retku bližnji je subjekt ljubavi. Naime, u Isusovu pitanju nije riječ više o bližnjem koji riskira da postane objekt, nego o čovjeku koji je postao bližnji ranjenomu, koji je aktivni subjekt uspostave odnosa (Weren, 2011, 90). Tako Samarijanac postaje istinski i pravi model ljubavi prema bližnjemu (Gourgues, 1998, 713).

»Idi pa i ti čini tako!« Isusove su posljednje riječi kojima poziva zakonoznanca, jednako tako i čitatelja svakoga vremena, na djela ljubavi i milosrđa. Slijedeći Samarijanca, koji s obzirom na hram, kult i vjeru nije imao nikakav kredibilitet, čitatelj je pozvan učiniti samoga sebe bližnjim čovjeku u potrebi, u dubokoj svijesti da bližnji nije onaj tko prima, nego tko daruje ljubav. Postati bližnji nekomu znači s velikim suosjećanjem zaštititi i pobrinuti se za potrebita. »Unesrećenom je bližnji postao Samarijanac, a Samarijanac čini milosrđe i na taj način ljubi stradalog čovjeka, svoga bližnjega. On ljubi i Boga jer daje da Bog po njemu djeluje. Ovdje uočavamo upravo ovu dinamičnu dimenziju — ne samo ljubiti bližnjega, činiti milosrđe drugome, nego i sam postati bližnji. 'Postati bližnji' označava gotovost i trajnost radnje. Bližnji je onaj koji baš uvijek iskazuje ljubav prema Bogu i onome tko mu je u blizini, jednako reagira na tuđu potrebu. To znači činiti zapovijed ljubavi, a ne ostati na statičnoj formuli«(Cifrak, 2012, 581). No, potrebno je naglasiti da se taj izbor ne događa zbog toga »što je čovjek u potrebi moj bližnji, nego zbog toga što sam ja u tom trenutku pozvan postati bližnji! Bližnji sam, dakle, ja a ne netko drugi! « (Weren, 2011, 90). »Bližnji je onaj koji baš uvijek iskazuje ljubav prema Bogu i onome tko mu je u blizini, jednako reagira na tuđu potrebu. To znači činiti zapovijed ljubavi, a ne ostati na statičnoj formuli« (Cifrak, 2012, 581).

\section{Odgovornost $i$ solidarnost ljubavi}

U svjetlu Lk 10,25-37 možemo reći da su odgovornost i solidarnost dvije temeljne značajke Isusova stava prema drugomu i drugačijemu. Etiku sadržanu u Shemà Isus je interpretirao u prispodobi o milosrdnom Samarijancu: ljubiti drugoga kao samoga sebe u njegovoj različitosti, u njegovoj individualnosti, u njegovu karakteru, u njegovoj osobnosti, u njegovu grijehu, u njegovim ranama, 
u njegovim potrebama (Grilli, 2012, 99). Riječ je o etici odgovorne i djelotvorne ljubavi, koja bez sumnje ima svoje izvore u samom zemaljskom Isusu, koji je ljubav prema bližnjemu proširio na ljubav prema svakomu čovjeku. »Ta etika vidi u ljubavi prema bližnjemu istinsko Bogoslužje srca koje mora prethoditi kultnoreligioznom bogoslužju « (Müller, 1996, 109).

U svojim susretima s hromima, slijepima, nijemima, gubavima, opsjednutima, odbačenima, marginaliziranima, grješnima, tuđincima i dr. kojima je vraćao puninu ljudskoga dostojanstva i integriteta, čineći ih dionicima zajednice spašenih, Isus nam otkriva da je naš bližnji svaki čovjek, bez obzira na njegovu religioznu, nacionalnu i spolnu pripadnost. Možemo reći da je za Isusa bližnji cjelokupno čovječanstvo, jer svi ljudi kao Božja stvorenja imaju pred Njim jednako dostojanstvo i jednaka prava (Tumbarello, 1991, 223). Isusov stav prema drugomu i drugačijemu stav je koji bi trebao resiti i život njegovih učenika, koji su pozvani prepoznati svoga bližnjega u svakom čovjeku, u dubokoj svijesti da na prvom mjestu nije pitanje vlastitoga "ja" (tko je moj bližnji), nego pitanje drugoga "ti" (komu sam ja bližnji) (Lujić, 2010, 225). U tom svjetlu Isusova zapovijed postaje univerzalna, bezuvjetna, bezgranična i svevremenska zapovijed ljubavi, koju su učenici svakoga vremena pozvani utjeloviti u svojem svakodnevnom "biti" i "činiti".

\section{Zaključak}

Odgovarajući na uvodna pitanja, u svjetlu prispodobe o milosrdnom Samarijancu (Lk 10,25-37), možemo zaključiti da su čitatelji svakoga vremena u susretu s drugim i drugačijim pozvani zauzeti Isusov stav sveobuhvatne i bezuvjetne ljubavi, pitajući se uvijek iznova ne "Tko je moj bližnji?", nego "Komu sam ja bližnji?" Put je to odgovorne i solidarne ljubavi, koja oslobođena od ropstva zakonskim, krvnim, nacionalnim i religioznim običajima i kriterijima prilazi čovjeku u potrebi, postajući njegov bližnji u punom i pravom smislu riječi.

Pri tome je, dakako, potrebno budno paziti da ne upadnu u zamku lažne i neautentične ljubavi koja oblikuje i definira bližnjega prema svojoj vlastitoj slici, koja čini nad njim nasilje, koja ga zarobljava, koja briše njegovu različitost, koja se skriva iza zakonskih propisa i običaja (Grilli, 2012, 99). Slijedeći primjer milosrdnoga Samarijanca, pozvani su, kao istinski Isusovi učenici, u susretu s bratom i sestrom, napose s onima koji su u potrebi, ne prelaziti na drugu stranu iz straha da se "onečiste" ili jednostavno misleći kako je to dužnost nekoga drugoga, nego učiniti sve što je u njihovoj moći kako bi sačuvali i zaštitili njihov život i ljudsko dostojanstvo jer, kao što kaže Dietrich Bonhoeffer (2009, 282), iza bližnjega kojega nam povjerava Kristov poziv nalazi se sam Bog. Onaj tko u drugom, pa i onom najudaljenijem ne prepoznaje svojega bližnjega, ne služi Bogu nego samomu sebi, bježeći od odgovornosti i skrivajući se u ograničenost udobnoga ispunjavanja dužnosti. Stoga, zaključuje Bonhoeffer, zapovijed ljubavi prema bližnjemu zakonski ne ograničava odgovornost na prostorno, građanski, 
profesionalno ili obiteljski bližnjega kojega susrećemo, jer naš bližnji može biti upravo u najudaljenijem, a najudaljeniji u bližnjem.

\section{Literatura}

Amerl, Rudolf (1997). Hebrejsko-hrvatski rječnik. Zagreb: Kršćanska sadašnjost.

Bauckham, Richard (1998). The Scrupulous Priest and the Good Samaritan: Jesus' Parabolic Interpretation of the Law of Moses. New Testament Studies, 44(4), 475-489.

Biblija. Adalber Rebić, Jerko Fućak i Bonaventura Duda (ur.), Biblija: Stari i Novi zavjet s uvodima i bilješkama iz La Bible de Jérusalem. Zagreb: Kršćanska sadašnjost, 2003.

Bonhoeffer, Dietrich (2009). Etika. Rijeka: Ex libris.

Bovon, François (2007). Vangelo di Luca 2. Brescia: Paideia.

Cifrak, Mario (2012). Idi pa i ti čini tako! (Lk 10,25-37). Bogoslovska smotra, 82(3), 575588.

Crimella, Matteo (2015). Luca. Cinisello Balsamo: San Paolo.

Ernst, Josef (2004). Antiparerhomai. U: Horst Balz i Gerhard Schneider (ur.), Dizionario esegetico del Nuovo Testamento (str. 293). Brescia: Paideia.

Fausti, Silvano (1994). Una comunità legge il Vangelo di Luca. Bologna: Edizioni Dehoniane Bologna.

Fitzmyer, Joseph A. (1985). The Gospel According to Luke X-XXIV: A New Translation with Introduction and Commentary. New York: Doubleday.

Fužinato, Silvana; Grilli, Massimo (2019). Riječ Božja u ljudskom jeziku. Tumačenje Biblije u komunikacijskoj perspektivi. Zagreb: Glas Koncila.

Gourgues, Michel (1998). The priest, the levite, and the Samaritan revisited: A critical note on Luke 10:31-35. Journal of Biblical Literature, 117(4), 709-713.

Grilli, Massimo (2012). L'opera di Luca: 1. Il Vangelo del viandante. Bologna: Edizioni Dehoniane Bologna.

Grilli, Massimo (2013). "L’altro" tra estraneità e accoglienza. U: Massimo Grilli i Joseph Maleparampil, Il diverso e lo straniero nella Bibbia ebraico-cristiana: Uno studio esegetico-teologico in chiave interculturale (str. 7-12). Bologna: Edizioni Dehoniane Bologna.

Just, Arthur A. (2006). Luca: La Bibbia commentata dai padri: Nuovo Testamento 3. Roma: Città Nuova.

Lujić, Božo (2010). Božja vladavina kao svijet novoga čovjeka. Zagreb: Kršćanska sadašnjost.

Maly, Angelo (2016). Prispodoba o milosrdnom Samarijancu. Idi pa i ti čini tako (Lk 10,25-37). Biblija danas, 2, 13-16.

Michelini, Giulio (2016). La comunicazione di Gesù e la misericordia: La parabola del buon Samaritano e il suo contesto (Lc 10,25-37). U: Giulio Michelini (ur.), I vangeli della misericordia (str. 52-84). Milano: Àncora.

Morris, Leon (1983). Luka. Novi Sad: Dobra Vest.

Müller, Paul-Gerhard (1996). Lukino evanđelje. Zagreb: Kršćanska sadašnjost.

Niccacci, Alviero (1992). Dall'aoristo all'imperfetto, o dal primo piano allo sfondo: Un paragone tra sintassi greca e sintassi ebraica. Studium Biblicum Franciscanum: Liber Annuus, 42, 85-108.

Nolli, Gianfranco (1993). Evangelo secondo Luca. Città del Vaticano: Libreria editrice Vaticana. 
Papinska biblijska komisija (2005). Tumačenje Biblije u Crkvi: Govor pape Ivana Pavla II. $i$ dokument Papinske biblijske komisije. Zagreb: Kršćanska sadašnjost.

Popović, Anto (2016). Grčko-hrvatski rječnik Novoga zavjeta sa statistikom grčkih riječi. Zagreb: Kršćanska sadašnjost.

Schottroff, Luise (2007). Le parabole di Gesù. Brescia: Queriniana.

Simian-Yofre, Horacio (2011). La esclerosis de la Palabra: la Escritura "Qué està escrito? Como lo lees?" (Lucas 10,26). Estudios Biblicos, 69, 55-77.

Spinetoli, Ortensio da (1982). Luca: Il Vangelo dei poveri. Assisi.

Tumbarello, Giacomo (1991). La parabola del buon Samaritano: Lettura etico-morale. Bibbia e oriente, 33, 223-231.

Walter, Nikolaus (2004). Splanhnizomai. U: Horst Balz i Gerhard Schneider (ur.), Dizionario esegetico del Nuovo Testamento (str. 1389-1391). Brescia: Paideia.

Weren, Wim (2011). Finestre su Gesù: Metodologia dell'esegesi dei Vangeli. Torino: Claudiana.

Zimmermann, Ruben (2011). Un amore toccante (Il buon Samaritano). U: Ruben Zimmermann (ur.), Compendio delle parabole di Gesù (str. 845-872). Brescia: Queriniana.

„Who is my neighbour?” (Lk 10:29)

Jesus' Relationship Towards „The Other” and to „People Who are Unlike Others” Silvana Fužinato*

\section{Summary}

The question of our relationship with "the other" and „people who are unlike others" is one of the fundamental existential issues that every man faces. Here we are asked to take a personal stand and act responsibly as we contemplate Jesus' teachings on love towards God and our neighbour. This article attempts to answer the question, „Who is my neighbour?” and to define Jesus' relationship towards "the other" and „people who are unlike others”. We reflect on Luke's gospel as Jesus enters Jerusalem for the last time, where Jesus invites all his disciples to build a radical and authentic relationship with God and their neighbour? To help illustrate the process of building this relationship, Luke employs a beautiful communication strategy. In Luke's gospel Jesus asks those learned in the law, „Who is your neighbour?” Rather than answer this question, Luke's gospel describes Jesus telling the parable of the Good Samaritan.

The Samaritan - in contrast to the priest and the Levite - encounters a naked man, severely beaten by thieves and left for dead on the street and

* Ph.D., Assistant Professor. Catholic Faculty of Theology in Đakovo, J. J. Strossmayer University, Osijek. Address: P. Preradovića 17, P. O. Box 54, 31400 Đakovo, Croatia.

E-mail: fuzinatosilvana@gmail.com 
does not cross the street to the other side to avoid him. Instead, the Samaritan shows compassion and extends to him a helping hand without expecting anything in return. It is through this parable that the reader is transformed.

At the end of His parable Jesus poses the following question to the law-makers concerning these three men: „Who was a neighbour to the man who fell victim to thieves?" The core question is not "Who is my neighbour?", rather it is, „To whom am I a neighbour?" It is in this ideational transformation that Jesus challenges our ideas and shatters our idea of our neighbour as it was understood at that time. Jesus asks His disciples throughout the ages to engage in an authentic and radical expression of the law of Love toward God and man.

Key words: Samaritan; Law; love; neighbour; responsibility; solidarity 